\title{
Cognitive process to evaluate serious games for the elderly
}

\author{
Sungjin Kim \\ Dept. of Media Contents, Graduate School \\ Dongseo University, San 69-1, Churye-dong, Sasang-gu, Busan, Korea \\ Mijin Kim \\ Division of Digital Contents \\ Dongseo University, San 69-1, Churye-dong, Sasang-gu, Busan, Korea
}

\begin{abstract}
This paper aims to propose a cognitive evaluation model to be utilized in designing game devices and developing relevant software with the purpose of the prevention of dementia of the elderly among various types of serious games for the elderly intending to improve their physical, mental or social capability. Firstly, a serious game for the elderly has been developed based on the guidelines of the areas pertaining to existing hardware, software and contents. Secondly, a pre-experiment of the game targeting specialists has been conducted in order to re-establish a cognitive evaluation model for the developed result. Thirdly, the cognitive evaluation model for the serious game for the elderly that intends to improve their cognitive capacity has been materialized based on the experiment results. Given the fact that the scope of game contents, most of which used to be focused on teenagers, have been gradually expanding to cover wider range of social classes than ever before, it is expected that the results of this study could be utilized as a model that can verify the games and their contents with special purposes based on the cognitive evaluation of the users.
\end{abstract}

Keywords: Serious Game for the Elderly, Dementia Precaution, Usability Evaluation

\section{INTRODUCTION}

Thanks to the advance of medicine and science, our societies are gradually aging. The Korean government statistics agency reported in 2007 that one out of ten people or 9.9\% of Korea's population was senior citizens (65 years old or more). Cultural spaces where senior people can spend their spare time have become one of essential matters; furthermore, the development of games which intend to achieve special purposes such as training, mentality, treatment or health improvement through game elements, not just a typical playing method based on traditional ways, has been demanded. Among such serious games, in particular, a game that aims to help improve physical health is generally called "Health Game" locally and abroad. Of course, the target of any health improvement scheme must not be limited to senior people. Therefore, it will be correct to say that the most practical attitude in developing a health game is to focus on creating a game that can be equally enjoyed by both young and old generations, although the consideration of the characteristics of the elderly in developing such a game should be a prerequisite. Human beings tend to express their emotions, relieve tension and develop capabilities to deal with

This is an excellent paper selected from the papers presented at ICCC 2009.

*Corresponding author.E-mail : mjkim@dongseo.ac.kr

Manuscript received May. 03, 2010 ; accepted Sep. 07, 2010 trauma or stress while playing. Since playing provides the player with pleasure most of all, anyone can easily indulge in playing without rejecting or resisting feeling; moreover, when a person becomes a player who can operate and make decisions for himself or herself on the play, he or she can develop selfesteem, achieve compensation for those activities that are not feasible in reality and seek for alternatives for adaptive behavior. With these reasons, a serious game for the elderly can be accepted as a method to prevent and treat physical, mental and social aging in consideration of their characteristics.

Most game platforms have been designed to meet young people's desires as they have been the main user group of games. "Table 1" contains the summary of the result of a survey research carried out by Andy Robertson ("What Gamers Want: Silver Gamers", Gamasutra Magazine, in July of 2008). It shows the overall cases of faulty program operation, places where games were played, issues related to the interface between a player and game devices, etc. through visual recording and in-depth interview with 50 male and 25 female game players [1].

Table 1. Game methods that silver gamers prefer

\begin{tabular}{|l|c|c|}
\hline \multicolumn{1}{|c|}{ Experiment Details } & Preferred & $\begin{array}{c}\text { Not } \\
\text { preferred }\end{array}$ \\
\hline 1. Repetitive tutorial & 0 & \\
\hline 2. Detailed instructions & 0 & \\
\hline
\end{tabular}




\begin{tabular}{|l|c|c|}
\hline $\begin{array}{l}\text { 3. Text size, time allowed for } \\
\text { reading }\end{array}$ & $\begin{array}{c}\text { Large, } \\
\text { Long }\end{array}$ & $\begin{array}{c}\text { Small, } \\
\text { Short }\end{array}$ \\
\hline 4. Use of technical game terms & & 0 \\
\hline $\begin{array}{l}\text { 5. Variety and distinction of } \\
\text { game materials }\end{array}$ & Activated & $\begin{array}{c}\text { Not } \\
\text { activated }\end{array}$ \\
\hline $\begin{array}{l}\text { 6. Multi-play and } \\
\text { communication functions }\end{array}$ & Sitting & Standing \\
\hline $\begin{array}{l}\text { 7. Posture during playing the } \\
\text { game }\end{array}$ & 0 & \\
\hline 8. Place set for game playing & & \\
\hline $\begin{array}{l}\text { 9. On-line based play with } \\
\text { other family members }\end{array}$ & $\begin{array}{c}\text { Short } \\
\text { (Several } \\
\text { minutes) }\end{array}$ & Long \\
\hline 10. Game duration & & \\
\hline
\end{tabular}

Even the summarized data in "Table 1" shows that there are differences between youth and silver generation in playing games, hence the interface and contents of a game, which meet requirements for hardware and software based on silver generation, must be reflected to the designing of a game. In other words, in order to develop a game for the elderly, existing game platforms need to be modified or transformed to meet their requirements, creation of new platforms and interfaces is necessary and, furthermore, in software aspect, the criteria for data recognition on the screen are required to be modified as well.

Among the commercialized games, Nintendo DS's brain training and Wii Fit's exercise game, which have been widely accepted by senior citizens, can be considered as the games that intend to deal with mental and physical aging matters, respectively. There are a wide variety of games besides them. In order to facilitate serious games for the elderly, what is required is to clearly define the categories of the games for the silver generation and to clarify the scope of each category, as exiting games have their own game genre depending on their purposes apart from the necessity for considering the issues pertaining to game platforms. According to Video Games and Health published by the U.S. Entertainment Software Association (ESA) in 2008, health games were classified into four categories[2][3].

"Table 2" shows that more systematic approach to the targets and more contents are required in order to promote serious games for the elderly while sharing necessary data and cooperating with relevant organizations for each category. While one of primary goals of normal games is providing 'Fun', the biggest target of serious games is 'functionality', hence effectiveness and efficiency - the evaluation criteria of those games are the most significant matters. According to the data in "Table 2", brain training games which belong to the category of Health Habits tend to have higher preference ratio in senior people than young people. This study has compared the results of the problem solving process using a pen and paper and using video game device; the problem solving process is the key part of the brain training game in the research of Lennart E. According to the test result, the group using a pen and paper was able to reduce task completion time with less error rates. However, it is also revealed that problem solving using a game device has aroused much higher metal stimulation (attention) and concentration than pen and paper. The evaluation criteria of such serious games are composed of Task Completion Time, Efficiency as Error Rate, Self-Assessment Measures: Arousal,
Pleasure, Dominance and Game Experience: Challenge, Flow, Competence, Tension, Positive and Negative Effect[4].

Table 2. Categories of Health Games

\begin{tabular}{|c|c|c|}
\hline Category & Goal & Applied to / Developed by \\
\hline $\begin{array}{l}\text { Physical } \\
\text { Fitness }\end{array}$ & $\begin{array}{l}\text { To Improve } \\
\text { perception (balance), } \\
\text { physical strength } \\
\text { and joint movement } \\
\text { through physical } \\
\text { motions }\end{array}$ & $\begin{array}{l}\text {-Pennsylvania state, Connellsville } \\
\text { Area School District } \\
\text {-Newyork, Parsippany Troy Hills } \\
\text { School District } \\
\text {-Dallas, Grace Presby Terian Village } \\
\text {-Gold's Gym, YMCA }\end{array}$ \\
\hline Healthy Habits & $\begin{array}{l}\text { To encourage } \\
\text { healthy habits }\end{array}$ & $\begin{array}{l}\text {-Robert Wood Johnson Foundation } \\
\text {-Kaiser Permanente Foundation } \\
\text {-visual impairments 'EYE SPY' } \\
\text {-HopeLab }\end{array}$ \\
\hline $\begin{array}{c}\text { Rehabilitation } \\
\text { Programs }\end{array}$ & $\begin{array}{l}\text { To help rehabilitation } \\
\text { from certain disease } \\
\text { or the aftermath of } \\
\text { an accident }\end{array}$ & $\begin{array}{l}\text {-USC, Virtual Iraq } \\
\text {-Duke Univ., Zack Rosenthal } \\
\text {-Psychologist, Deborah Stokes, }\end{array}$ \\
\hline $\begin{array}{l}\text { Medical } \\
\text { Training }\end{array}$ & $\begin{array}{l}\text { Provide information } \\
\text { on treatment and } \\
\text { health care }\end{array}$ & $\begin{array}{l}\text {-The Office of Naval Research, } \\
\text { BreakAway, 'Pulse' } \\
\text {-The Entertainment Technology } \\
\text { Center at Carnegie Mellon, 'Hazmat' }\end{array}$ \\
\hline
\end{tabular}

\section{PRECEDING STUDY}

In "Serious Game Design for the Elderly using Arcade Game Machines"[5], which was the preceding study of this thesis, first, 'Three principles for utilizing anthropometric data' and the standard body types of Korean males and females in their 60 s were used as models for designing machinery structure; second, applicable items among the evaluation criteria presented by 'Jacob Nielsen and Melissa A. Federoff' were adopted for the purpose of contents architecture; third, standards meeting the contents of 'dementia rehabilitation program', which has three stage program of cognitive, memory and reflexive abilities as medical experiment models were presented.

Based on these standards, hardware structures (see Figure 1.) was designed and contents for improving cognitive ability of senior people (see Table 3.) were developed into three different stages.

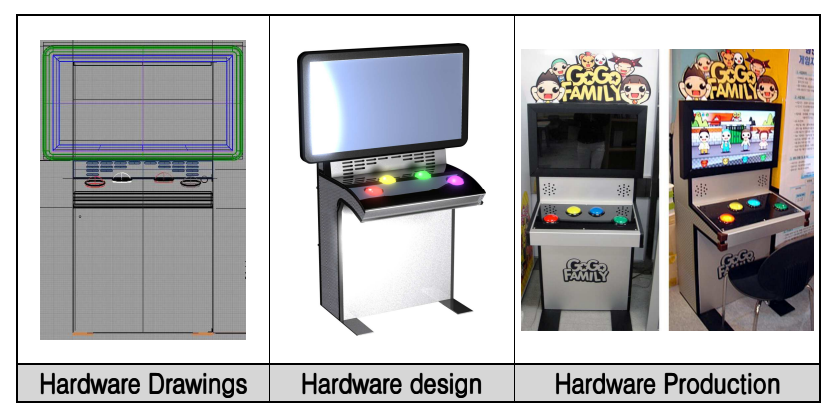

Fig. 1. Hardware design for serious games for the elderly[5] 
Table 3. Software design for serious games for the elderly [6]

\begin{tabular}{|c|c|c|}
\hline Stage & Graphic Design & Design Rule \\
\hline $\begin{array}{l}\text { Cognition Game } \\
\text { (Basic Level) }\end{array}$ & $\begin{array}{l}\text { Memory } \rightarrow \text { Differentiation } \\
\Rightarrow \text { Impression } \\
\Rightarrow \text { Result }\end{array}$ & $\begin{array}{l}\text {-Is there any unnecessary } \\
\text { information for the game? } \\
\text {-Is it possible to do } \\
\text { immediate timing } \\
\text { and feedback? } \\
\text {-Is there a consistency in } \\
\text { the visual interface? } \\
\text { - Would it increase the skill } \\
\text { through repetition? } \\
\text {-Is it easy and convenient } \\
\text { to control? }\end{array}$ \\
\hline $\begin{array}{c}\text { Simple } \\
\text { Recognition }\end{array}$ & $\begin{array}{l}\text { - Cognitive ability heavily } \\
\text { people' s psychological } \\
\text { elements including intellig } \\
\text { - Training helps them inc } \\
\text { the situation and recogniz }\end{array}$ & $\begin{array}{l}\text { affects various types of aged } \\
\text { processes defining cognitive } \\
\text { ence and memory ability. } \\
\text { rease abilities to study, judge } \\
\text { e places and time. }\end{array}$ \\
\hline $\begin{array}{l}\text { Memory Game } \\
\text { (Middle Level) }\end{array}$ & $\begin{array}{l}\text { Visual and Auditory } \\
\text { Stimulus } \rightarrow \text { Memory } \rightarrow \\
\text { Differentiation } \rightarrow \text { Memory } \\
\rightarrow \text { Differentiation } \rightarrow \\
\text { Repetition } \rightarrow \text { Recollection } \\
\Rightarrow \text { Result }\end{array}$ & $\begin{array}{l}\text {-Would it increase the skill } \\
\text { through repetition? } \\
\text {-Is there a consistency in } \\
\text { the visual interface? } \\
\text {-Does it minimize the } \\
\text { memory burden for a user } \\
\text { and does it help to } \\
\text { improve concentration and } \\
\text { attention and have clear } \\
\text { targets? } \\
\text {-Can a user check real- } \\
\text { time the score and level and } \\
\text { Is the layer-menu well } \\
\text { arranged? }\end{array}$ \\
\hline $\begin{array}{c}\text { Synthetic } \\
\text { Recollection }\end{array}$ & \multicolumn{2}{|c|}{$\begin{array}{l}\text {-Memory refers to the ability to recollect what a person } \\
\text { has studied and experienced; aging is chiefly related to } \\
\text { short-term memory loss. } \\
\text {-It increases the time duration of keeping experiences } \\
\text { in memory and the ability to study and solve recognized } \\
\text { problems. }\end{array}$} \\
\hline $\begin{array}{l}\text { Reaction Game } \\
\text { (Advanced Level) }\end{array}$ & $\begin{array}{l}\text { Visual and Auditory } \\
\text { Stimulus } \rightarrow \text { Memory } \rightarrow \\
\text { Differentiation } \rightarrow \text { Memory } \\
\rightarrow \text { Differentiation } \rightarrow \\
\text { Repetition } \rightarrow \text { Recollection } \\
\Rightarrow \text { Result }\end{array}$ & $\begin{array}{l}\text {-Is it possible to do } \\
\text { immediate timing and } \\
\text { feedback in the gaming } \\
\text { situation? } \\
\text {-Does it consist of } \\
\text { interesting visual and audio } \\
\text { effects? } \\
\text { - Would it increase the skill } \\
\text { through repetition? } \\
\text {-Is there a consistency in } \\
\text { the visual interface? }\end{array}$ \\
\hline $\begin{array}{l}\text { Comprehensive } \\
\text { Brain } \\
\text { Function/Reaction }\end{array}$ & \multicolumn{2}{|c|}{$\begin{array}{l}\text {-Reflexive ability indicates the capacity to understand } \\
\text { new concepts with respect to the reaction velocity to } \\
\text { stimulation; new neuropsychological skill (such as } \\
\text { capability to play an instrument) decreases as growing } \\
\text { old. } \\
\text {-Capabilities to save information, make a judgment on } \\
\text { an unexpected situation and react instantly are } \\
\text { improved. }\end{array}$} \\
\hline
\end{tabular}

\section{THEORETICAL BACKGROUNDS}

\subsection{Consideration of Usability Evaluation}

Usability means to measure the experience degrees of users' interactions with product's system and is composed of the elements affecting the experience of the users. Products, which are made by the commercial viability complying with the users' desire for using, need to meet those desires and promote a smooth interaction between users and products. In order to achieve that, basic design principles that make a product easy to understand and use for human beings. First, a good conceptual model has to be provided; second, a visual result, which can be verified by visually, has to be made; third, correspondence relationship has to be fixed to ensure behavior and its results, operation and its effects, and system status to be visually recognized; fourth, a sufficient amount of feedback on the results of behavior must be constantly provided to users. Both usability test and social science research belong to 'empirical method' in that they observe actual behaviors [7].

\subsection{Reference Model for Evaluation}

Quality in use indicates overall qualities including effectiveness, efficiency and satisfaction that users feel when they performing tasks using system in various actual operation environment including social, physical and technological environment. ISO9241-11 specifically addresses the definition of usability as effectiveness, efficiency and satisfaction[8]. Also, those criteria that are related to the easiness of study, which becomes the goal of usability, the achievement of convenience and the attributes of usability including efficiency, accuracy, meaning, flexibility and consistency, are widely accepted as bases in developing software. The direction of cognitive evaluation model is set on the basis of factors meeting reference items for Nielsen's questions to evaluate the usability, which were set as references of development model of serious games for the elderly.

Table 4. Nielsen's usability evaluation criteria meeting experimental task

\begin{tabular}{|c|c|}
\hline $\begin{array}{c}\text { Reference } \\
\text { model }\end{array}$ & Description \\
\hline Learnability & $\begin{array}{l}\text {-An item which is to be considered in the beginning of use, } \\
\text { in particular. However, high initial learnability doesn' t always } \\
\text { mean the high efficiency in long-term performance. } \\
\text {-Programs for beginners tend to be learned quickly; } \\
\text { however, the efficiency is not increased even if they are fully } \\
\text { learned. On the other hand, programs for experts take longer } \\
\text { time to learn initially but have high efficiency rate once } \\
\text { proficiency is attained. }\end{array}$ \\
\hline Efficiency & $\begin{array}{l}\text {-The performance level that can be shown by a user who has } \\
\text { correctly learned how to use } \\
\text {-An efficient system indicates a system that allows users } \\
\text { who have attained proficiency to accomplish task goals } \\
\text { within short period of time making less effort[9]. }\end{array}$ \\
\hline Memorability & $\begin{array}{l}\text { - In case of a product or software that is used not very often, } \\
\text { people tend to be troubled often because they cannot } \\
\text { remember how to use it. In order to prevent such problem, } \\
\text { the use of product has to be easy to remember. } \\
\text { - Memorability is not a huge issue in case of a product that is } \\
\text { used frequently because the use of the product is not } \\
\text { forgettable; however, it is an important issue for those } \\
\text { products that have to be used only once in a certain period } \\
\text { of time. }\end{array}$ \\
\hline $\begin{array}{c}\text { Error } \\
\text { tolerance }\end{array}$ & $\begin{array}{l}\text {-Programs with less possibility of error occurrence are } \\
\text { recommended, if possible. However, the occurrence of errors } \\
\text { is unavoidable, the system has to ensure that the occurrence } \\
\text { of an error is easily recognizable and fixed so that the result }\end{array}$ \\
\hline
\end{tabular}




\begin{tabular}{|c|c|}
\hline & $\begin{array}{l}\text { of an unavoidable error won' t result in a critical failure. } \\
\text {-For example, Microsoft' s Windows allows an easy } \\
\text { restoring deleted files from Recycle Bin'. }\end{array}$ \\
\hline Satisfacti & $\begin{array}{l}\text {-It refers to the degree of the satisfaction or pleasure given } \\
\text { to users when using a product or system; it is considered to } \\
\text { be an important factor for entertainment or home shopping } \\
\text { channels[10]. }\end{array}$ \\
\hline
\end{tabular}

\subsection{Evaluation Methods}

Selecting a proper test method is an essential process to guarantee a smooth progress of evaluation and acquire a reliable result by securing more accurate information on quality. In this study, we've selected such methods as questionnaire surveys, interviews, user preferences on questionnaires and question-asking protocol which meet the purpose of this experimental task among the ways to secure usability utilized in HCI research. When conducting questionnaire surveys, interviews and user preferences on questionnaires, the length and amount of questions have been decided and a brief explanation on the questions that were not understood easily has been provided in consideration of low capacity of senior people to read and understand.

Question-asking protocol method means to react more actively rather than simply waiting for the responses of users. In order to help senior people understand questions better, an experiment conductor asked questions orally. Users could listen to and understand the questions through auditory function and give their answers orally, which have been marked or recorded by the conductor.

\section{COGNITIVE EVALUATION MODEL}

Based on the reference model and evaluation methods presented in Chapter 3, this study provides a concrete evaluation model on the hardware structure and software architecture of the serious game for the elderly developed through preceding study in Chapter 3 and cognitive evaluation processes (see Table 5).

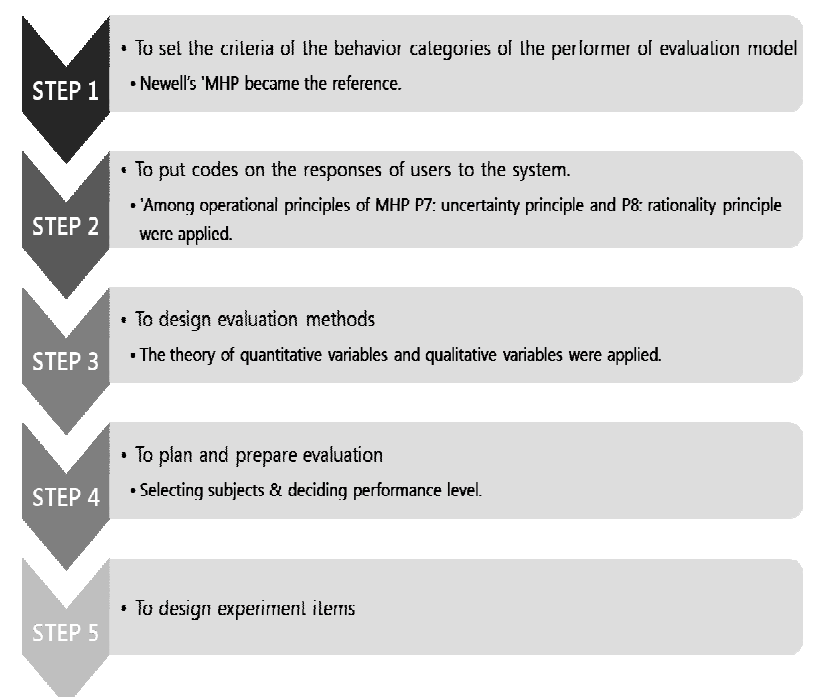

Fig. 2. The development procedure of a cognitive evaluation model

4.1 Category of Cognitive Behavior

The model human processor of Newell has been selected as the reference to categorize the behaviors of performers in order to establish cognitive evaluation model of serious games for the elderly. The model to put codes on the responses of users to the system is composed of P7: uncertainty principle and P8: rationality principle among operational principles of the model human processor (MHP) [11].

The cognitive reactions of users' behavioral processes have been coded into 5 categories as shown in "Table 5"

Table 5. Putting codes on users' cognitive reactions

\begin{tabular}{|c|c|c|c|}
\hline \multicolumn{2}{|c|}{ Behavioral Category } & Code & Reaction; users \\
\hline \multicolumn{2}{|c|}{ SEE } & $S$ & look at the screen \\
\hline \multicolumn{2}{|c|}{ Simple cognitive } & SC & $\begin{array}{l}\text { listen to the instructions on } \\
\text { how to play the game }\end{array}$ \\
\hline \multicolumn{2}{|l|}{ Listen to } & $L$ & $\begin{array}{l}\text { listen to background music of } \\
\text { the game. } \\
\text { listen to button sound of the } \\
\text { game. }\end{array}$ \\
\hline \multicolumn{2}{|c|}{ Complex cognitive } & $\mathrm{CC}$ & play a game. \\
\hline \multirow{3}{*}{ Reaction } & $\begin{array}{l}\text { By pressing } \\
\text { the button }\end{array}$ & $\mathrm{R}-\mathrm{PB}$ & $\begin{array}{l}\text { show a reaction of pressing the } \\
\text { button after complex cognitive. }\end{array}$ \\
\hline & Non Reaction & $\mathrm{R}-\mathrm{NR}$ & $\begin{array}{l}\text { show no reaction after complex } \\
\text { cognitive. }\end{array}$ \\
\hline & Question & $R-Q$ & $\begin{array}{l}\text { request an explanation on the } \\
\text { situation again after complex } \\
\text { cognitive }\end{array}$ \\
\hline
\end{tabular}

\subsection{Empirical Evaluation Methods}

The evaluation methods to acquire the value of user reactions through experiment have been presented in "Table 6". For both areas of hardware and software, "quantitative variables and qualitative variables theories' of Schneier and Mehal, which are widely used in evaluating human and machinery usability, were used.

Table 6. Empirical evaluation methods

\begin{tabular}{|c|c|}
\hline Quantitative Variables Theory & Qualitative Variables Theory \\
\hline User preferences on questionnaires & Protocol analysis \\
\hline \multicolumn{2}{|c|}{ Evaluation in laboratory } \\
\hline Evaluation of achievement & Evaluation of process \\
\hline $\begin{array}{l}\text { Comprehensive evaluation of } \\
\text { system' s final performance }\end{array}$ & $\begin{array}{l}\text { Formative evaluation for correction } \\
\text { and improvement }\end{array}$ \\
\hline $\begin{array}{l}\text { Quantitative evaluation based on } \\
\text { surveys of multiple number of groups }\end{array}$ & $\begin{array}{c}\text { Qualitative evaluation based on in- } \\
\text { depth analysis on small number of } \\
\text { groups }\end{array}$ \\
\hline
\end{tabular}

The experiment utilizes evaluation in laboratory, which is mainly used for conducting an accurate assessment of specific parts such as standards or regulations under a properly controlled environment among empirical evaluation methods that the system is evaluated by actual users. A Laboratory evaluation is divided into process evaluation and performance evaluation depending on the purpose of the assessment. The process evaluation is used to find out what users thought or what difficulties they encountered during the use of a certain system. It is also considered to be a formative evaluation 
method that intends to correct or improve the system based on the analysis results and will be applied to the protocol analysis method of qualitative variables theory. On the other hand, performance evaluation is a method to assess how fast the users of the system have accomplished given tasks while making how many errors during the performance. It is a summative evaluation method to assess the appropriateness of system's performance level; user preferences on questionnaires based on quantitative variables theory will be applied.

\subsection{Selection of Testees}

Subjects to be tested will be senior citizens who will become the main user group of serious games in fact and the user group will consist of only one group composed of beginners who have no prior experience of playing the game. It is because of the characteristics of silver generation. Since they have very less likely experienced those new contents - games, if they have to be classified into smaller groups in accordance with detailed criteria, few game users meeting the requirements of each group may exist. It will make the process of survey more difficult. The experiment will examine the performance rate of novice users under the currently given restrictions. Based on the results, the basis for a game design method for beginners can be prepared[12]. Every testee will be required to participate in the experiment after being given instructions on how to play game one time only without having any prior experience in all the experimental stimuli. The maximum number of users to be asked will be no more than 12 people. It is because the possibility of finding additional system errors dramatically decrease when there are more than 12 participants[8]. Subject groups will be selected from the senior citizens who are in between 50 years old or older and 75 years old or younger, regardless of their educational background or living conditions, and classified into the groups of Young-old, Middle-old and Old-old, respectively.

\subsection{Performance Level Decision}

The experiment results of each platform have been classified into three units in order to decide their performance level. For example, it means a hypothesis that their performance shall reach a certain level albeit they are in silver generation who are not familiar with game contents. More specifically, provided current level is 0 , users shall reach at least more than 5/1 (20\%) within the three-stage time limit. Adequate level is $5 / 3(60 \%)$ which means that users with no prior experience can achieve more than half success or it indicates the achievement rate of its final goal or functional effect that can be obtained by the users within a short period of time. If testees can achieve more than $5 / 3$ after having only one time of explanation without any prior experience at all, the content structure, configuration, interface and designing architecture taking into account user interactions of the game are considered to have suitable level and applied to the result analysis on the experiment. The highest goal is over $5 / 4(80 \%)$. The maximum level has been set to rather high because it is a mini-scale game for senior people that doesn't necessarily draw a conclusion based on judgment and recognition on complex situation for long period of time.
Table 7. Performance criteria of cognitive evaluation model

\begin{tabular}{|c|l|}
\hline $\begin{array}{c}\text { Performance } \\
\text { level }\end{array}$ & \multicolumn{1}{|c|}{ Expected effect } \\
\hline Lowest & $\begin{array}{l}\text { Minimum level that can be achieved whenever } \\
\text { playing the developed game [Over 1/5 (20\%)] }\end{array}$ \\
\hline Adequate & $\begin{array}{l}\text { Suitable level that has reached the actual goal of } \\
\text { the game; no additional evaluation or modification } \\
\text { is required. [Over 3/5 (60\%)] }\end{array}$ \\
\hline Highest & $\begin{array}{l}\text { Well developed and can positively affect the users; } \\
\text { completely ready to be commercialized. } \\
{[\text { Over 4/5 (80\%)] }}\end{array}$ \\
\hline
\end{tabular}

\section{LABORATORY EVALUATION}

This study only contains the results of laboratory experiment conducted on an expert group prior to carrying out experiment on senior people. A laboratory experiment is considered to be a preliminary verification to prepare a main experiment on multiple number of subjects. Experiment method is presented in "Table 6" and concrete survey questions are made.

\subsection{Experiment Details}

The expert group for the laboratory evaluation is composed of those people who are recommended for 'constructing usability evaluation team'. Two samples were selected from each group of HCI expert (assessor), system developer (planning), designer (graphic) and programmer. In order to draw calculation results of evaluation results to make behavior categories, 5 points are given to each question and the full marks of the 20 questions is 100 points.

Questions about software are constructed at three stages (cognitive, memory and reflexive abilities), each of which contains 5 questions making total 15 questions. Questions about hardware are composed of 5 questions throughout the entire stage. All questions are multiple choices using 5-point scale evaluation. Qualitative analysis experiment will be conducted for those testees who belong to the medium group of the satisfaction distribution that has been drawn from the satisfaction ratio against playing time based on quantitative analysis experiment.

"Table 8" shows the reference contents of questionnaire for quantitative and qualitative analyses on hardware and software. GOMS[13], which is one of the best quantitative analysis methods on interface area, will be used for hardware analysis. GOMS modeling allows forecasting how much time a user spends carrying out a certain task through given interface.

Table 8. Criteria of cognitive evaluation model questionnaire

\begin{tabular}{|c|c|l|}
\hline \multirow{2}{*}{$\begin{array}{c}\text { Key feature } \\
\text { of system }\end{array}$} & $\begin{array}{c}\text { Selection basis } \\
\text { for experiment } \\
\text { task }\end{array}$ & \multicolumn{1}{|c|}{ Questions about } \\
\hline \multirow{2}{*}{ Learnability } & $\begin{array}{c}\text { System's } \\
\text { basic value }\end{array}$ & $\begin{array}{l}\text { whether functional aspects have been } \\
\text { realized? [ Software ] }\end{array}$ \\
\cline { 3 - 4 } Efficient & $\begin{array}{l}\text { Symiliarity with the device before playing the } \\
\text { system }\end{array}$ & bame [ Hardware ] \\
\hline basic value & $\begin{array}{l}\text { whether each cognitive cycle has been } \\
\text { processed smoothly [ Software ] }\end{array}$ \\
\cline { 3 - 4 } & & satisfaction level after finishing each game \\
\hline
\end{tabular}




\begin{tabular}{|c|c|l|}
\hline & & $\begin{array}{l}\text { stage for cognitive, memory and reflexive } \\
\text { abilities. [Hardware] }\end{array}$ \\
\hline Memorability & $\begin{array}{c}\text { Issue } \\
\text { forecasting }\end{array}$ & $\begin{array}{l}\text { errors expected by the developer through } \\
\text { Heuristic assessment [ Software ] }\end{array}$ \\
\hline $\begin{array}{c}\text { Low error } \\
\text { rate }\end{array}$ & $\begin{array}{c}\text { Require } \\
\text { improvement }\end{array}$ & $\begin{array}{l}\text { frequent disconnection due to low } \\
\text { understanding level of game contents; } \\
\text { unexpected question. [ Software ] }\end{array}$ \\
\hline $\begin{array}{c}\text { User } \\
\text { satisfaction }\end{array}$ & $\begin{array}{c}\text { System' s finallin each stage [ Software ] } \\
\text { goal }\end{array}$ & $\begin{array}{l}\text { satisfaction level on game' s configuration } \\
\text { satisfaction level on the use of the device } \\
\text { after completing the game [ Hardware ] }\end{array}$ \\
\hline
\end{tabular}

\subsection{Questionnaire Composition}

Quantitative and qualitative methods have been applied to each stage question based on "Table 6" and "Table 8". In this study, any overlapped matters per each stage will not be repeated and be recorded one time only.

\subsubsection{Quantitative Evaluation: Software}

What is your overall feeling about the game? (User' s satisfaction level) [Common]

\begin{tabular}{|c|c|c|c|c|}
\hline 5 & 4 & 3 & 2 & 1 \\
\hline \multicolumn{4}{|c|}{ 5: Similar to very easy / very convenient / very satisfied } & \multirow{5}{*}{$\begin{array}{l}\text { Marked by the } \\
\text { conductor, } \\
\text { considering } \\
\text { testers are } \\
\text { senior citizens }\end{array}$} \\
\hline \multicolumn{4}{|c|}{ 4: Similar to easy / convenient / satisfied } & \\
\hline \multicolumn{4}{|c|}{ 3: Similar to Okay / I don' t know/ Normal } & \\
\hline \multicolumn{4}{|c|}{ 2: Similar to inconvenient / difficult / not satisfied } & \\
\hline \multicolumn{4}{|c|}{$\begin{array}{l}\text { 1: Similar to very inconvenient / very difficult / Neve } \\
\text { want to do it again }\end{array}$} & \\
\hline
\end{tabular}

Was there anything unnecessary in the game? [Stage 1]

Was the content understandable when playing the game in repetition? [Stage 2]

\begin{tabular}{|c|c|c|c|c|}
\hline \multicolumn{5}{|c|}{ Was the game process smooth enough? [Stage 3] } \\
\hline 5 & 4 & 3 & 2 & 1 \\
\hline \multicolumn{5}{|c|}{ Was the game process smooth enough? [Stage 1] } \\
\hline \multicolumn{5}{|c|}{ Was the display configuration consistent? [Stage 2] } \\
\hline \multicolumn{5}{|c|}{ Did rhythm, actions, character design attract your interest? [Stage 3] } \\
\hline 5 & 4 & 3 & 2 & 1 \\
\hline \multicolumn{5}{|c|}{ Was the display configuration consistent? [Stage 1] } \\
\hline \multicolumn{5}{|c|}{$\begin{array}{l}\text { Nas it difficult to remember the flow of the game due to too high difficul } \\
\qquad \text { level? [Stage2] }\end{array}$} \\
\hline \multicolumn{5}{|c|}{$\begin{array}{l}\text { Was it easy to understand the contents of the game when played in } \\
\text { repetition? [Stage 3] }\end{array}$} \\
\hline 5 & 4 & 3 & 2 & 1 \\
\hline \multicolumn{5}{|c|}{ Was it easy and convenient to manipulate? [Stage 1] } \\
\hline \multirow{2}{*}{\multicolumn{5}{|c|}{$\begin{array}{l}\text { Was overall menu configuration formed well, so that you could check } \\
\text { score at any time? [Stage 2] } \\
\text { Was the visual configuration consistent? [Stage 3] }\end{array}$}} \\
\hline & & & & \\
\hline 5 & 4 & 3 & 2 & 1 \\
\hline
\end{tabular}

\subsubsection{Quantitative Evaluation: Hardware}

Was the exterior of the device designed to properly respond to user' s operation? [Operator]

\begin{tabular}{|c|c|c|c|c|}
\hline 5 & 4 & 3 & 2 & 1 \\
\hline \multicolumn{4}{|c|}{ 5: Similar to very easy / very convenient / very satisfied } & \multirow{4}{*}{$\begin{array}{l}\text { Marked by the } \\
\text { conductor, } \\
\text { considering } \\
\text { testers are } \\
\text { senior citizens }\end{array}$} \\
\hline \multicolumn{4}{|c|}{ 4: Similar to easy / convenient / satisfied } & \\
\hline \multicolumn{4}{|c|}{ 3: Similar to Okay / I don' t know/ Normal } & \\
\hline \multicolumn{4}{|c|}{ 2: Similar to inconvenient / difficult / not satisfied } & \\
\hline
\end{tabular}

\begin{tabular}{|c|c|c|c|c|}
\hline \multicolumn{5}{|c|}{$\begin{array}{l}\text { 1: Similar to very inconvenient / very difficult / Never } \\
\text { want to it again }\end{array}$} \\
\hline \multicolumn{5}{|c|}{ Was it possible to manipulate everything you want? [Intention] } \\
\hline 5 & 4 & 3 & 2 & 1 \\
\hline \multicolumn{5}{|c|}{ Was the exterior designed to attract your interest in the game? [Goal } \\
\hline 5 & 4 & 3 & 2 & 1 \\
\hline \multicolumn{5}{|c|}{$\begin{array}{l}\text { Was it designed to let you know the current status of the game? } \\
\text { [Selected rule model] }\end{array}$} \\
\hline 5 & 4 & 3 & 2 & 1 \\
\hline \multicolumn{5}{|c|}{ Was there any difficulty or inconveniency? [Method] } \\
\hline 5 & 4 & 3 & 2 & 1 \\
\hline
\end{tabular}

5.2.3 Qualitative Evaluation: Software

\begin{tabular}{|c|c|c|c|c|c|c|c|}
\hline \multicolumn{8}{|c|}{$\begin{array}{l}\text { What is your overall feeling after completing this stage? } \\
\text { [User satisfaction] }\end{array}$} \\
\hline 5 & 4 & 3 & & \multicolumn{3}{|c|}{2} & 1 \\
\hline \multicolumn{7}{|c|}{ 5: Similar to very funny / very interesting / very satisfied } & \multirow{5}{*}{$\begin{array}{l}\text { Marked by the } \\
\text { conductor, } \\
\text { considering } \\
\text { testers are } \\
\text { senior citizens }\end{array}$} \\
\hline \multicolumn{7}{|c|}{ 4: Similar to funny / interesting / satisfied } & \\
\hline \multicolumn{7}{|c|}{ 3: Similar to expected / I don' t know / normal } & \\
\hline \multicolumn{7}{|c|}{ 2: Similar to not funny / difficult / not satisfied } & \\
\hline \multicolumn{7}{|c|}{$\begin{array}{l}\text { 1: Similar to too boring / very difficult / never want to do } \\
\text { it again }\end{array}$} & \\
\hline $\begin{array}{l}\text { Reaction } \\
\text { Code }\end{array}$ & $\begin{array}{l}\text { Situation } \\
\text { explanation }\end{array}$ & Feature & \multicolumn{5}{|c|}{ Question } \\
\hline \multirow{2}{*}{$\begin{array}{c}(\mathrm{S})- \\
(\mathrm{SC})- \\
(\mathrm{R}-\mathrm{PB})\end{array}$} & \multirow{2}{*}{$\begin{array}{c}\text { After } \\
\text { completing a } \\
\text { practice } \\
\text { game }\end{array}$} & \multirow{2}{*}{ Learnability } & \multicolumn{5}{|c|}{$\begin{array}{l}\text { Did you understand the explanation } \\
\text { on the game? }\end{array}$} \\
\hline & & & 5 & 4 & 3 & 2 & 1 \\
\hline $\begin{array}{l}\text { Reaction } \\
\text { Code }\end{array}$ & $\begin{array}{l}\text { Situation } \\
\text { explanation }\end{array}$ & Feature & & & & lesti & \\
\hline \multirow{2}{*}{$\begin{array}{c}(\mathrm{S})- \\
(\mathrm{CC})- \\
(\mathrm{R}-\mathrm{PB})\end{array}$} & \multirow{6}{*}{$\begin{array}{c}\text { After } \\
\text { completing } \\
\text { more than } 2 \\
\text { times of } \\
\text { playing }\end{array}$} & \multirow{6}{*}{$\begin{array}{l}\text { Efficient } \\
\text { system }\end{array}$} & \multicolumn{5}{|c|}{$\begin{array}{l}\text { Were the game process smooth and } \\
\text { the play time adequate? }\end{array}$} \\
\hline & & & 5 & 4 & 3 & 2 & 1 \\
\hline \multirow{2}{*}{$\begin{array}{c}(S)- \\
(C C)- \\
(R-N R)\end{array}$} & & & \multicolumn{5}{|c|}{$\begin{array}{l}\text { Were the game process smooth and } \\
\text { the play time adequate? }\end{array}$} \\
\hline & & & 5 & 4 & 3 & 2 & 1 \\
\hline \multirow{2}{*}{$\begin{array}{l}(S)- \\
(C C)- \\
(R-Q)\end{array}$} & & & \multicolumn{5}{|c|}{$\begin{array}{l}\text { Were the game process smooth and } \\
\text { the play time adequate? }\end{array}$} \\
\hline & & & 5 & 4 & 3 & 2 & 1 \\
\hline $\begin{array}{l}\text { Reaction } \\
\text { Code }\end{array}$ & $\begin{array}{l}\text { Situation } \\
\text { explanation }\end{array}$ & Feature & & & & desti & \\
\hline \multirow{2}{*}{$\begin{array}{c}(\mathrm{S})- \\
(\mathrm{SC})- \\
(\mathrm{R}-\mathrm{PB})\end{array}$} & \multirow{4}{*}{$\begin{array}{c}\text { When a } \\
\text { wrong } \\
\text { answer is } \\
\text { given during } \\
\text { playing }\end{array}$} & \multirow{4}{*}{$\begin{array}{l}\text { Low error } \\
\text { rate }\end{array}$} & \multicolumn{5}{|c|}{$\begin{array}{l}\text { Was the game difficult? (Give } 5 \\
\text { points if there is no wrong answer) }\end{array}$} \\
\hline & & & 5 & 4 & 3 & 2 & 1 \\
\hline \multirow{2}{*}{$\begin{array}{c}(\mathrm{S})- \\
(\mathrm{CC})- \\
(\mathrm{R}-\mathrm{NR})\end{array}$} & & & \multicolumn{5}{|c|}{$\begin{array}{l}\text { Was the game difficult? (Give } 5 \\
\text { points if there is no wrong answer) }\end{array}$} \\
\hline & & & 5 & 4 & 3 & 2 & 1 \\
\hline $\begin{array}{l}\text { Reaction } \\
\text { Code }\end{array}$ & $\begin{array}{l}\text { Situation } \\
\text { explanation }\end{array}$ & Feature & & & & & $\begin{array}{l}\text { periment tasks } \\
\text { ncurred by }\end{array}$ \\
\hline
\end{tabular}




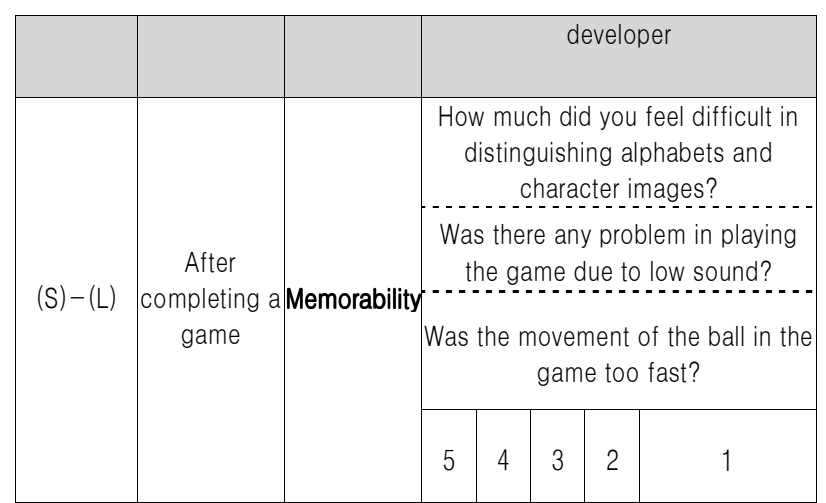

5.2.4 Qualitative Evaluation: Hardware

\begin{tabular}{|c|c|c|c|c|}
\hline \multicolumn{5}{|c|}{$\begin{array}{l}\text { What is your over feeling about the device aft } \\
\text { entire game? } \\
\text { [User satisfaction] }\end{array}$} \\
\hline 5 & 4 & 3 & 2 & 1 \\
\hline \multicolumn{4}{|c|}{ 5: Similar to very easy / very convenient / very satisfied } & \multirow{5}{*}{$\begin{array}{l}\text { Marked by the } \\
\text { conductor, } \\
\text { considering } \\
\text { testees are senior } \\
\text { citizens }\end{array}$} \\
\hline \multicolumn{4}{|c|}{ 4: Similar to easy / convenient / satisfied } & \\
\hline \multicolumn{4}{|c|}{ 3: Similar to Okay / I don' t know/ Normal } & \\
\hline \multicolumn{4}{|c|}{ 2: Similar to inconvenient / difficult / not satisfied } & \\
\hline \multicolumn{4}{|c|}{$\begin{array}{l}\text { 1: Similar to very inconvenient / very difficult / Never } \\
\text { want to do it again }\end{array}$} & \\
\hline \multicolumn{5}{|c|}{$\begin{array}{l}\text { Did you have any reluctance about the game device before starting the } \\
\text { game? } \\
\text { [Learnability] }\end{array}$} \\
\hline 5 & 4 & 3 & 2 & 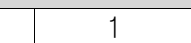 \\
\hline \multicolumn{5}{|c|}{$\begin{array}{l}\text { What was the uncomfortable level of using the device (buttons and } \\
\text { posture) when completing } 1 \text { stage? [Ease of use] }\end{array}$} \\
\hline 5 & 4 & 3 & 2 & \begin{tabular}{l|l} 
& 1
\end{tabular} \\
\hline \multicolumn{5}{|c|}{$\begin{array}{l}\text { What was the uncomfortable level of using the device (buttons and } \\
\text { posture) when completing } 2 \text { stage? [Ease of use] }\end{array}$} \\
\hline 5 & 4 & 3 & 2 & 1 \\
\hline \multicolumn{5}{|c|}{$\begin{array}{c}\text { What was the uncomfortable level of using the device (buttons and } \\
\text { posture) when completing } 3 \text { stage? [Ease of use] }\end{array}$} \\
\hline 5 & 4 & 3 & 2 & 1 \\
\hline
\end{tabular}

\subsection{Evaluation Results}

The qualitative laboratory experiment on an expert group has been conducted on selected four subjects whose quantitative results of satisfaction level are the most approximate to the average value. The results are as shown in "Table 10".

Table 9. Percentage of quantitative evaluation results

\begin{tabular}{|c|c|c|c|c|c|c|}
\hline Classification & Cognitive & Memory & Reflexive & $\mathrm{S} / \mathrm{W}$ & $\mathrm{H} / \mathrm{W}$ & Total \\
\cline { 1 - 2 } $\mathrm{HCl}$ expert 1 & 23 & 23 & 23 & 69 & 22 & $\underline{91}$ \\
\hline$\underline{\mathrm{HCl} \text { expert 2 }}$ & 20 & 18 & 20 & 58 & 22 & $\underline{80}$ \\
\hline Planning 1 & 24 & 25 & 23 & 72 & 23 & 95 \\
\cline { 1 - 2 } Planning 2 & 20 & 20 & 20 & 60 & 20 & $\underline{80}$ \\
\hline Graphic 1 & 23 & 20 & 22 & 65 & 24 & $\underline{89}$ \\
\hline Graphic 2 & 20 & 17 & 23 & 60 & 19 & 79 \\
\hline Program 1 & 24 & 23 & 23 & 70 & 24 & 94 \\
\hline Program 2 & 19 & 17 & 22 & 58 & 18 & 76 \\
\hline \% & 83.2 & 86.5 & 81.5 & 88 & 86 & 85.5 \\
\hline
\end{tabular}

Table 10. Percentage of qualitative evaluation results

\begin{tabular}{|c|c|c|c|c|c|c|}
\hline Classification & Cognitive & Memory & Reflexive & $\mathrm{S} / \mathrm{W}$ & $\mathrm{H} / \mathrm{W}$ & Total \\
\hline $\mathrm{HCl}$ expert 1 & 23 & 24 & 21 & 68 & 25 & 94 \\
\hline $\mathrm{HCl}$ expert 2 & 25 & 24 & 22 & 71 & 24 & 95 \\
\hline Planning 2 & 21 & 21 & 23 & 65 & 21 & 86 \\
\hline Graphic 1 & 24 & 24 & 21 & 65 & 23 & 88 \\
\hline$\%$ & 93 & 93 & 87 & 89.4 & 93 & 90.7 \\
\hline
\end{tabular}

\section{CONCLUSION AND FURTHER DISCUSSIONC}

This thesis describes the cognitive evaluation model of those games that have special functional purposes for senior citizens by separating them into hardware and software parts. In order to propose an evaluation model, an actual game has been developed as a part of preceding research and I've proposed a cognitive evaluation model meeting the requirements of serious games for the elderly through conducting analyses on previous usability evaluation models and laboratory evaluation. . Given the fact that the scope of game contents, most of which used to be focused on teenagers, have been gradually expanding to cover wider range of social classes than ever before, it is expected that the results of this study could be utilized as a model that can verify the games and their contents with special purposes based on the cognitive evaluation of the users.

\section{ACKNOWLEDGMENTS.}

Human Resource Training Project for Regional Innovation

This research was financially supported by the Ministry of Education, Science Technology (MEST) and Korea Institute for Advancement of Technology(KIAT) through the Human Resource Training Project for Regional Innovation

Industry \&Education Collaboration Business through The Small \& Medium Business Administration of Korea Government.

\section{REFERENCES}

[1] Andy Robertson, "What Gamers Want: Silver Gamers", Gamasutra Magazine, 2008.7.

[2] Entertainment Software Association (2008), "Video games and Health", Retrieved from http://www.theesa.com/ gamesindailylife/health.asp.

[3] Peter Smith (2009), "Video/Online Games for Health Come of Age : Four Major Trends Now Emerging", Retrieved from http://www.gamesforhealth.org/archives/000223.html.

[4] Lennart E. Nacke, Anne Nacke, Craig A. Lindley, "Brain Training for Silver Gamers: Effects of Age and Game Form on Effectiveness, Efficiency, Self- Assessment, and Gameplay Experience", CyberPsychology \& Behavior, vol. 12, no. 5: 493-499, October 9, 2009.

[5] Sungjin Kim, Mijin Kim, "Serious Game Design for the Elderly using Arcadf Game Machines", Journal of the 
Korea Contents Association vol. 9, no. 7, pp.11 17, 2009.7.

[6] Sungjin Kim, Mijin Kim, " A study of suitability of arcade platform to apply for the elderly serious game", ICCC2009. pp.711-712.

[7] Dumas, 1988: Gould \& Lewis, 1995: Rubenstein \& Hersh, 1984: Shneiderman, 1992.

[8] Kim, Jinwoo, HCI Introduction, Ahn graphics, 2008.04, p.191, p615.

[9] Park, Changho and others, Psychology of Cognitive Engineering: Understanding of interactions between human beings and system, Sigma Press, 2007.9, p.213.

[10] Lee, Jungmo and others, Cognitive Psychology, Hakjisa, 2009, p.526.

[11] Allen Newell, Unified Theories of Cognition, President ang Fellows of Harvard College, 1990, pp.61 64.

[12] Song, Seungkeun, Gamers' Cognitive Process on Gameplay in Massively Multi-player Online Role-Playing Game: Towards World of Warcraft Players, Doctoral dissertation, Yonsei Graduate Program in Cognitive Science, 2006. 12, p.45.

[13] GOMS : model of goals, operators, methods, and selection rules by Card, Moran, and Newell,1983.

[14] Kim, Jinwoo, Digital Contents @HCI Lab, Youngjin.com, 2002, p.548.

[15] Kim, Changsu, "A Study on User-Classification for Usability Evaluation”, KAIST, 1996, pp. 5 6, p.18.

[16] Jef Raskin, humane interface, ahn graphics, 2003, p.96.

[17] Joseph S. Dumas, Janice Redish, WritingA Practical Guide to Usability Testing Revised Edition, Hansom Media, 2004.

[18] Yang, Dongju, Ergonomics \& Design, Minyoungsa, 2009.

[19] Kim, Dongyoun and others, Dementia Prevention \& Cognitive Rehabilitation Programs, Seohyunsa, 2004.

[20] Choi, Sungjae, Jang, Inhyup, Welfare for the Aged, Seoul National University, 2006.

[21] Jung, Donghun, "Cognitive Development Evaluation of Haptic Puzzle Game Using a Haptic Pen”, Korea Game Society, vol. 9, no. 4, August 2009.

[22] Song, Seungkeun and Lee, Juyeon, "An Exploratory Approach to Textile Designer's Cognition Model", The Korean Society for Emotion and Sensibility, vol. 6. no 1, May. 2003.

[23] Kim, Gyungmi and Jang, Munyoung" The Analysis of Cognitive Reaction Time to the Intensity of Auditory Stimuli in Older People", Korean Academy of Sensory Integration, vol. 5, no.1, January. 2007.

[24] Park, Cheolheung, Development of usability evaluation model for games, Graduate School of Computer and Information Technology, Sangmyung University. Master's thesis, 2002.

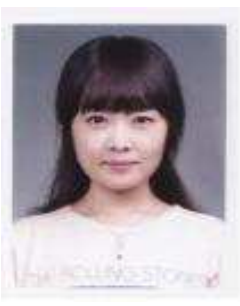

\section{Sungjin Kim}

The author of this study is currently researching visual contents in the doctorate course in the graduate school of Dongseo University. She studied design in undergraduate and postgraduate courses and has had many exhibition experiences as a figurative artist. With a huge interest in serious games, cognitive engineering, usability evaluation and smart phone games, she is conducting a research on serious games for the elderly currently.

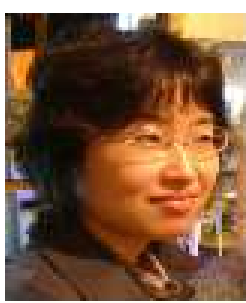

\section{Mijin Kim}

She is currently a Professor in Games, Division of Digital Content, Dongseo University, Korea. Before joining Dongseo University, She had experiences of commercial game development at game company(Min Communication, LTD). And then she was a researcher at the department of image information engineering at Pusan National University. Her research interest in the computer game design : level design, game interface, emotional model form aspects of HCI. She has managed a laboratory(game entertainment studio). This Lab has processed several game projects with related commercial game companies. With a background in both technology and creative development, She specializes in game design research into the creative development process. Her research was also chosen for 2009 National Research Foundation of Korea Grant funded by the Korean Government. 